\title{
Screen language: visual - expressive means of the television image
}

\author{
I. S. Putsiata \\ National University "Lviv Polytechnic" \\ Corresponding author. E-mail: Iryna.S.Putsiata@1pnu.ua
}

Paper received 24.02.19; Accepted for publication 12.03.19.

\section{https://doi.org/10.31174/SEND-HS2019-199VII33-22}

\begin{abstract}
In the work screen language research was conducted - visual - expressive means of the television image, analysis is carried out of visual - expressive means of television channels: «1+1» and «Inter». The article focuses on the fact that one of the most striking trends of formatting of television projects today is a realization of the game as the basis for the formation of the screen language. The game involves bringing the TV program closer to the public, which in turn generates no passive contemplation, and attracting the viewer into the process.
\end{abstract}

Keywords: television, television program, visual-expressive means, TV image

In an era of global consumption of scientific and technical discoveries in the panel of semantic shades it becomes more difficult to distinguish between true meanings and values. Television, as one of the leading contemporary media, plays a key role, which forms the culture, which helps the viewer make a choice in the space of the world with the help of the formed reflected reality. In the context of visualization processes TV with its specific set of expressive means becomes the main channel of broadcasting in the society of socio-cultural values.

The relevance of this research is dictated by the need give a detailed, thorough analysis of the modern approach to the use of means of artistic expression on television. Active transformation of audiovisual media, which is noted by many researchers, seriously needs a systemic evaluation. Study of the transformation of the form and format of TV programs in connection with the change of socio-cultural, techno-technological, the economic situation of our time, it is important not only to preserve the creative potential of journalism, but also for the development of society as a whole. On the one hand, the transformation of the screen language reflects the general processes of civilization development, timely understanding of which is extremely important in the aspect of scientific reflection. On the other hand, these changes in the media have a significant impact on the socio-cultural process, and therefore they are in dire need of objective and operational scientific evaluation.

Today, when television is often rebuked by a large number of low-quality programs, when the research confirms the influence of screen content on the formation of the basic values and needs of the audience, it is especially important to identify the key trends in the development of the television language. The transition to a market economy and the market as a whole involves the transition to another system of relations, to the new components of interaction, which determines the formation of a special culture of communication. Everything that is connected with the spiritual development of the person, with great difficulty can adapt to a market-based way of existence. Modern teleproducts are increasingly perceived as goods. Meanwhile, television cultural and educational programs are needed even in the harsh conditions of the media market to preserve imagery, metaphor, and multidimensionality.

The question of creating a visual image was investigated by the following scientists: E. Iefimovym, K. Rozlogovym, M. Stuflyaevoyu, R. Kuznetsovym, A.
Yurovskym. The problem of television participation in the preservation and formation of cultural norms formed the basis of works: A. Vartanov, V.Vilchek, S. Muratov, N.Froltsova. About the nature of the impact of audiovisual media on culture, wrote: V. Yegorov, B. Sapunov, E. Kozlov, V. Sappak, E. Sabashnikova. The processes of modern media transformation studied: N. Goryunova, D. Dondurei, A. Kachkajeva, T. Lebedeva. However, the expressive means of the screen were not considered comprehensively from the point of view of their participation in the formation of the cultural and educational sphere as translators and creators of traces in the context of modern socio-cultural processes. The purpose of the work is to study the language of the screen - visual-expressive means of television image (for example, TV channels "1 +1 " and "Inter"). In accordance with the purpose of the work, the following tasks should be solved: to study the language of the screen and the use of visual-expressive means of television image; outline the features of the language of the journalists; to analyze the trails that are used by TV presenters as figurative visual-expressive means.

Media, as the main source of information dissemination, plays a leading role in formation the cultural community. Depending on the chosen means and their combination, the author determines not only the format of the television story, but also the general sense of the taste of the public, imaginative thinking of the viewer. We can talk about the reverse effect, when socio-cultural practices determine what will be interesting for viewer to see, what he wants to know and in what format it would be more convenient for him to perceive this information "here and now".

On the modern television, various means of enhancing visualization and expressiveness of the language are used, and an active appeal to which transforms various spheres of manifestation of verbal culture [6, p.59].

S. Eisenshtein wrote: " Actually, art begins with the moment when the combination of sound and image no longer simply reproduces the existing in the nature communication, but the connection is established, necessary for the tasks of expressiveness of the work "[9, p. 235].

Even at the information level, the message can get a special form. Synthesis of visual and audiovisual means of expressiveness helps the author in solving creative tasks. During the Asian flood in the news programs of various TV channels, a plot on the topic of disaster was included. For example, "UA: PERSHYI" showed a pic- 
ture of the apocalypse: in the frame were inflatable boats on the football field. In short, in a few words behind the scenes the author commented on the situation, and before the viewer there were several pictures at once. At the junction of those paintings he saw on the screen, and what still impressed the imagination of the viewer, there was sympathy, which prompted the participation in humanitarian assistance to the victims.

As D. Harms wrote, the power laid down in words must be liberated. There are such combinations of words in which the effect of force becomes noticeable. It's not good to think that this force will force things to move. I am sure that the power of words can do this "[4, p. 558].

Modern television, as an open-source system with nonlinear feedback, is a powerful word manager. Therefore, journalists in their practice often use the principle of metamorphic (Greek meta - before, after). Under the metamorphosis is understood "sign system that exists to describe the natural language" [8, p. 334]. In this case, the thought of Hegel would be appropriate. He believes that for any logical system there is such a statement, which can not be proved or refuted, remaining within the framework of this system. From this follows the idea of metamorphosis: a description of speech processes will occur only if we go beyond the language.

That is, metalanguage is the true thoughts of the interlocutor hidden in his words and expressions. The main purpose of using these words on the TV screen is to mitigate the verbal strike, which helps us manipulate the interlocutor, reaching our own goals. Often, journalists of allUkrainian TV channels, as part of a metamorphosis, use rhetorical questions, what the viewer directs to the view, which is true, but which is forbidden to speak. A good example can be Alexander Dubinsky's plot about the current situation in Ukraine: "Who is to blame for the theft of state property? Maybe the leadership of the state? "(MONEY 1 + 1, 03.02.2019).

Larysa Zadorozhna in a television message (The draft resolutions on the early termination of powers have already been registered today, though, in addition to "Liberty" and "Motherland". Their colleagues from the "Motherland" put forward their demands), by means of a metalanguage, trying to tell the viewer the true situation that occurred on Verkhovna Rada session. This information can be interpreted in such a way that the draft resolution for so much time has been registered, in spite of the comments and amendments made to it by the party "Motherland" (Details, Inter 30.01.2019).

On modern television, authors often turn to the use of trails as a vivid expressive means. In the journalistic text, the trails play a special role: the two-stage use of the word, in which its sound realizes simultaneously two values - allegorical and literal, connected with each other or on the principle of complexity (synecdoche, metonymy), or similarity (metaphor), or opposition ( irony).

Often, we can hear the metaphors on the air of the TV channel " $1+1 "$. It is more often compared to the inanimate and the living: "the truck breathed on incense" (about the causes of a car accident), (TSN. $1+1$. 18.02.19). Regarding the political programs of the channel, very often the object of metaphorization of them are generalizing concepts: "The world is tired of threats," "The world balances on the brink of war" (Right to pow- er. $1+1.07 .02 .19)$. Alla Mazur, TV presenter for " $1+1$ ", often uses metaphors: "Midnight cowboy chases along roads without mufflers, numbers and rights." This metaphor does not carry a negative disdainful evaluation of the leading representatives of the informal association of rockers, , it arises as a result of associations of the representative of this association on a "steel horse" (motorcycle) with a cowboy on a horse. In addition, we can hear metonymy (the transfer of the properties of one subject or phenomenon to another based on the principle of their adjacency (material - a product of it, the product - its manufacturer, action - an instrument of action): 02 will call 01 too late (plot about the fire in the building ) (TSN. Tyzhden'. 1+1. 10.02.19). The use of personification (a kind of metaphor consisting of transferring the properties of a person to inanimate objects or abstract concepts) is also characteristic of the language of the leading:

a) The country was flown by a forward-looking initiative.

b) The holiday re-forms city patriotism.

For greater expressiveness, Alla Mazur uses comparisons in his speech (convergence of two subjects or phenomena to explain one of them with the help of another): The President, as the Queen of England, was out of suspicion (TSN. Week $1+1,10.02 .19$ ).

Fine metaphors are abundant on the Inter Channel, many divorces of actress pairs are often marked by bursting of family photographs of the ether (characteristic prickly torn edge), sometimes even without a verbal commentary (Concerned by Everyone Inter 05.02.19.)

The leading of the Inter channel, Dauhulie Anastasia often uses one component of the case-law: "At the concert, for those for whom thirty, act as those under sixty. In addition to the pensioner Mika Jagera, in the world there is no other to show "Where did rock music go?" "(The author synthesizes the speech game of the phraseological level, namely, the play of stable turnover" those for whom thirty ", including the similar syntactic design "those for whom sixty", as well as the expansion of the meaning of the concept of "pensioner" by age with the processing of playoffs of case-law texts) (Morning Inter., 31.01.19). Another bright verbal expressive means in modern television content - allegory. Allegory (spellings) - an image of an abstract concept with the help of a particular image - is also common in modern television broadcast.

Phraseologisms can fulfill the role of not only noticeable names, but also witty, born "on the go" statements (quasi-phraseologisms), which can subsequently turn into stable language education. In the language of modern media phraseologisms (both intuitive and quasiphraseological) in order to enhance expressiveness and emotional influence can undergo various transformations.

Television practice has already produced certain techniques of such a modification of stable combinations. Of course, the task of the journalist - to find an accurate, bright word - it would be extremely simple if all the receptions could be used mechanically. But it is no coincidence that Otto Espersen (a famous Danish linguist) called the phraseology "a capricious and imperceptible thing": virtually every word in the phraseologism in one way or another changes its semantics. Changes in the first place depend on how close the words "rubbed" to each other, that is, the degree of cohesion of the components. 
A favorite technique in the texts of modern media is the various transformations of phraseologisms. The possibility of their transformation follows from the preservation of the internal form of phraseology, its original, literal meaning and relative stability. Transformation can be subject both to semantics and the structure of phrases. Transformation of semantics of phraseologisms is possible because they have an internal form, which allows authors to "restore" in one way or another erase the image and adapt the generalized, metaphorical meaning of a particular expression to specific context conditions.

A more complex stylistic approach to redefining phraseologisms is to use them simultaneously in two meanings - direct and portable. Often, the author helps the reader to understand the phraseologic pun, emphasizing that the phrase is used both literally and figuratively, composing the appropriate context.

In semantic transformations, one and the same phrase is perceived as both semantically integral, indissoluble, stable, and as free, that is semantically decomposed. In linguistic literature, there are different terms that call a similar phenomenon: "the synthesis of two meanings", "the expansion of phraseology", "modification of phraseologism," "actualization of the internal form of phraseologism." We believe that semantically transformed phraseologisms are nothing more than phraseological puns.

Creating a phraseological turn goes through several stages. First, a certain phrase begins to serve to indicate a repeating situation or its part, then there is a reduction to the general concept frame, without details. As a result, the link between actual and etymological values remains only an image-motive that creates associations and is of interest to the viewer. The phraseological game, combinations and variations on the topic of traditional phraseology allow you to "pack" in a short, which sounds like a slogan, the main idea of the news.

Interaction of artistic and television language is the most relevant today. One can notice that under the influence of artistic culture, television emphasizes a certain form of filing material, the use of expressive means of artistic culture. And, conversely, there are rapid changes in the artistic language of various types of art under the influence of modern television content [2, p. 60].

Modern technology allows not only high-quality synchronous recordings, but also the use of multi-line editing and high-precision work with video and sound recordings. As a result, within the framework of the programs of cultural and educational subjects, we get the following opportunities:

- qualitative reproduction of works of culture and art in various forms;

- comprehensive display of the object;

- precision reproduction of visual details;

- prompt and diverse information about events in the field of culture and art;

- interactive interaction with the viewer;

- restore archived records;

- "styling" in antiquity or a certain visual image;

- expansion of the possibilities of reconstruction of historical events [p, c. 196].
Active appeal to the above-mentioned possibilities of the modern screen changes the figurative system of work and forms new approaches to the use of expressive means of creating television content. The new language of television has a significant impact on the development of cultural practices in modern society.

Despite the complex conditions of creativity TV figures intensively studied onscreen language, mastered the artistic and expressive means of the screen, increasingly used its image and sound capabilities in the fullest possible.

In all categories where there is a picture, the picture on the television will probably have more information. In addition to the information, it still has the character of reasoning. The artistic image proposed by the authors, recreates the world with all its complex problems at a higher level. The artist does not just copy the reality, but interprets it in figurative form, creating an on-screen image of a phenomenon or an individual.

The entire cultural situation today in the totality of the entire telecommunications system is subject to analysis and consideration through the description of the leading audiovisual images reproduced by television channels. Thus, the most common images in the media space are images of "honest ruler", "rich and successful life", "strong nation". In the representation of the leading images of consciousness, formed by television, the main component is a qualitative characteristic.

Conclusions. In the conditions of the information market, hard competition, struggle for the media viewer, the authors seek to "pack" their products as attractively as possible, that is, to submit information in the most noticeable, characteristic form. This is the so-called "language game", an intellectual warming that attracts the attention of the public, so when composing voice-over texts and program titles it is necessary to select bright, noticeable, witty expressions.

Consequently, modern television content synthesizes sound and images that provide widespread dissemination of information and the broadcasting of cultural values. This fact allows us to conclude that the modern information space of audiovisual culture and communication dominates.

Research of visual-expressive means on television can become the basis for further development of methods of interaction of television journalists with viewers because the article has actual scientific and practical significance, gaining a special significance for the social and spiritual life of a person in the framework of the formation of the information society. At the same time, an in-depth analysis of the influence of a TV journalist on the audience, rather modest, in the domestic and foreign literature a tangible lack of specialized works devoted to the mentioned problems, which predetermined the choice of the topic of the article for research. Therefore, the question of the influence of visual-expressive means in projection on viewers is a promising direction for further research, because within the article only a certain aspect of the problem is covered. 


\section{ЛIТЕРАТУРА}

1. Алфьорова 3. І. Культурологічні підходи до масового візуального / 3. І. Алфьорова // Вісн. Харк. держ. акад. дизайну і мистец. [Сер.] Мистецтвознав. Архітектура: зб. наук. пр. - Х., 2007. - № 2. - С. 8-15.

2. Алфьорова 3. I. Формування сучасного масмедійного простору (англо-мовна література з проблеми) / 3. І. Алфьорова // Вісн. Харк. держ. акад. культури: зб. наук. пр. - Х., 2001. - Вип. 8. - С. 60-67.

3. Денисюк Ж. 3. Телебачення як система ідентифікацій і конструювання реальності / Ж. З. Денисюк // Актуальні проблеми історії, теорії та практики художньої культури: зб. наук. пр. / М-во культури і туризму України, Держ. акад. кер. кадрів культури і мистец., Київ. нац. ун-т ім. Т. Шевченка. - К.: Міленіум, 2007. - Вип. 19. - С. 196204.

4. Цит. за: Джойс Д. Собр. соч: в 3 т. Т. 3./ Д. Джойс. - М. : Знаменитая книга, 1994. - С. 558.

5. Зубавіна I. Нові екранні технології: специфіка комунікативної дії. Віртуалізація світу як стратегія «нуль дистанції» / I. Зубавіна // Сучасне мистецтво: зб. Ін-ту проблем сучасного мистецтва Академії мистецтв Укра-їни. - К. : «Акта», 2004. - Вип. 1. С. 246-241.

6. Зубавіна I. Б. Екранна культура: філософські інтенції сучасної теоретичної думки // Художня культура. Актуальні проблеми: зб. наук. пр. Вип. ІІ. — К.: АМУ, 2005. C. 59-74.

7. Иоскевич Я. Б. Категории аудиовизуального / Я. Б. Иоскевич // Новые аудиовизуальные технологии. - М., 2005.

8. Українська мова: Енциклопедія / Редкол.: Русанівський В. М. (співголова), Тараненко О. О. (співголова), М. П. Зяблюк та ін. - К. : Українська енциклопедія, 2004. - 824 с.

9. Яковець А. В. Телевізійна журналістика: теорія і практика: [підручник] / А. В. Яковець; А. В. Яковець. - К.: «Вид. дім Києво-Могилян. акад.», - 239 с. - Бібліогр.: c. $235-239$.

\section{REFERENCES}

1. Alfiorova Z. I. Culturological approaches to mass visual / Z. I. Alfiorova // Vysn. Hark state acad. design and art. [Sir.] Arts. Architecture: Sb. sciences Ave. - Kh., 2007. - No. 2. - P. 815.

2. Alfiorova Z. I. Formation of modern media space (Englishlanguage literature on the problem) / Z. I. Alfiorova / / Visn. Hark state acad. of culture: sciences Ave - Kh., 2001. - Vo. 8. - P. 60-67.

3. Denysyuk Zh. Z. Television as a system of identification and design of reality / Zh. Z. Denysyuk // Actual problems of the history, theory and practice of artistic culture: Sb. sciences пр. / M-culture and tourism of Ukraine, State. acad. manager frames of culture and arts., Kiev. nats Untitled $\mathrm{T}$. Shevchenko. - K.: Millennium, 2007. - Vip. 19. - P. 196-204.

4. Tsit. for: Joyce D. Sabr. Soch: in 3 t. T. 3. / D. Joyce. - M.: The Famous Book, 1994. - P. 558.

5. Zubavina I. New onscreen technologies: the specifics of communicative action. Virtualization of the world as a strategy of "zero distance" / I. Zubavina // Contemporary Art: $\mathrm{Sb}$. Other problems of contemporary art of the Academy of Arts of Ukraine. - K.: Act, 2004. - Vip. 1. pp. 246-241.

6. Zubavina I. B. Screen culture: philosophical intentions of modern theoretical thought // Art culture. Topical Issues: Sb. sciences пр. Вип. II - К .: AUC, 2005. - Р. 59-74.

7. Ioskevich Ya.B. Categories of audiovisual / Ya.B. Ioskevich // New audiovisual technologies. - M., 2005.

8. Ukrainian language: Encyclopedia / Redecorate: Rusanivsky V.M. (co-chairman), Taranenko O.O. (co-chairman), M.P. Zyablyuk, and others. - K.: Ukrainian Encyclopedia, 2004. 824 pp.

9. Yakovets AV Television journalism: theory and practice: [textbook] / AV Yakovets; AV Yakovets - K .: "Kind. House of Kyiv Mohyla. acad. ", - 239 p. - The bibliographer: p. 235239. 